sists in the simplicity of their construction, the economy of working, the absence of danger, (for there is nothing in them which can occasion explosion, ) and the advantage of their being always ready for action. These recommendations particularly adapt them for raising; water, drainage, mill machinery, \&c. There is one object which they will accomplish to which the steam is not applicable: in large buildings, or public works, they may be applied to fire engines of any power, which may be put into instantaneous action by gas supplied from the mains in the streets, and any quantity of water may thus be thrown to any height at a moment's notice.

Ibid.

\title{
Improvement in the quality of Iron and Steel, from their becoming. rusty when buried in the earth.
}

The following "extract from Chronicles of Old Jondon Bridge," is sufficiently curious in itself to merit insertion in the Plilosophical Magazine and Journal of Science, and as an instance of observation ingenious/y applied.

An eminent London cutler, Mr. Weiss, of the Strand, to whose inventions modern surgery is under considerable obligations, has remarked, that steel seemed to be much improved when it bad become rusty in the earth, and provided the rust was not facitiously produced by the application of acids.* He accordingly buried some razor blades for nearly three years, and the result fully corresponded to his expectations; the blades were coated with rust, which had the appearance of having exuded from within, but were not eroded, and the quality of the steel was decidedly improved. Analogy led to the conclusion, that the same might hold good with respect to iron under similar circumstances; so with perfect confidence in the justness of his views, be purchased, as soun as an opportunity offered, all the iron, amounting to fifteen tons, with which the piles of London Bridge had been shod. Each shoe consisted of a sinall inverted pyramid, with four straps rising from the four sides of its base, which embracm ed and were nailed to the pile; the total length from the point which entered the ground to the end of the strap being about sixteen inches, and the weight about eight pounds.

The pyramidal extremities of the shoes were found to be not much corroded, nor indeed were the straps; but the latter had become extremely and beautifully sonorous, closely resembling in tone the bars and sounding pieces of an Oriental instrument which was exhibited some time since with the Burmese state carriage. When manufac-

* This enterprising artist has informed me, that " some years since, he sent with Capt. Parry, in his voyage to the North Pole, some steel, which was constantly exposed on deck in the northem latitudes without being in the slightest degree rusted, but on arriving in a warmer and moistcr atmosphere, it became so. This steel he found very good, but not equal to that from London Bridge." 
tured, the solid points in question were convertible only into very inferion steel: the same held grood with respect to such bolts and other parts of the iron work as were subjected to the experiment, except the straps; these, which in addition to their sonorousness, possessed a degree of toughness quite mapproached by common iron, and which were, in fact, imperfect carburets, produced steel of a quality infinitely superior to any which in the course of his business Mr. Weiss harl ever before met with; insomuch that while it was in general request among the workmen for tools, they demanded higher wages for working it. 'These straps, weighing al together about eight tons, were consequently separated from the solid points, and these last sold as old iron.* The exterior differmed between the parts of the same shoe led at first to the supposition that they were composed of two sorts of iron; but, besicles the utter improbability of this, the contrary was proved by an examination, which led to the inference that the extremities of the piles having been charred, the straps of iron closely wedged between them, and the stratum in which they were imbedded must have been suljected to a galvanic action, which in the course of some six or seven hundred years gradually produced the effects recorded in the present paper.

T. J. H.

[Philosophical Magazine.

\section{Hancock's Steam Coach at Brighton.}

To the Ficlitor of the Mcchanies' Magazinc.

Sir,-Having received an intimation that Mr. Walter Hancock's steam carriage, the "Infant," was on the road to this place on an experimental trip, I went to meet it at eight miles on the London road yesterday morning, and come with it from thence in to Brighton. We travelled at the rate of between five and six miles per hour up the steep hill at Pie-Comb, and descended at the rapid rate of full thirteen miles per hour, proceeding afterwards steadily in to the town, at ten miles per hour. Mr. Hancock made a detour round the North Steyne enclosure, up to the palace gate, and returned to the Tank near the new church, where he stopped half an hour to take in coke and water, and proceeded immediately on his return to London.

This unexpected visit excited very great interest along the road and in the town, and caused an instantancous assemblage of the entire neighbourhood, who greeted Mr. Hancock with three hearty cheers. I understand from some of the gentlemen who accompanied

* A successful application of genius or observation is rarely heard of without some one endeavouring to reap the benefit, or the credit, of the discovery, while entitled to neither, nor perhaps understanding the principle on which it depends. 'The fume of Mr. Weiss' steel soon spread, when another person immediately purchased the bolts and fastenings of the old bridge: the articles manufactured from them will answer equally well as relics. 